\title{
Global Trade and Indian Politics The German Dye Business in India Before 1947
}

\author{
Lubinski, Christina
}

Document Version

Accepted author manuscript

Published in:

Business History Review

DOI:

$10.1017 / \mathrm{S} 0007680515000707$

Publication date:

2015

License

Unspecified

Citation for published version (APA):

Lubinski, C. (2015). Global Trade and Indian Politics: The German Dye Business in India Before 1947. Business History Review, 89(3), 503-530. https://doi.org/10.1017/S0007680515000707

Link to publication in CBS Research Portal

\section{General rights}

Copyright and moral rights for the publications made accessible in the public portal are retained by the authors and/or other copyright owners and it is a condition of accessing publications that users recognise and abide by the legal requirements associated with these rights.

Take down policy

If you believe that this document breaches copyright please contact us (research.lib@cbs.dk) providing details, and we will remove access to the work immediately and investigate your claim. 


\section{Global Trade and Indian Politics: The German Dye Business in India before 1947}

\section{Christina Lubinski}

Journal article (Post print version)

This article was originally published in Business History Review. Published online: 14 August 2015.

DOI: http://dx.doi.org/10.1017/S0007680515000707

Uploaded to Research@CBS: September 2015

Available at: $\underline{\text { http://research.cbs.dk/da/publications/global-trade-and-indian- }}$ politics \%282b10a456-76e8-406e-9fe2-efa0fe927cd8\%29.html

(C) 2015 Cambridge University Press

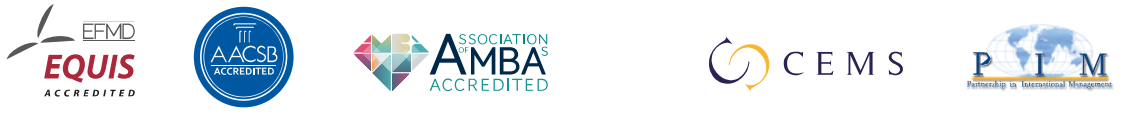




\title{
Christina Lubinski
}

\section{Global Trade and Indian Politics: The German Dye Business in India before 1947}

\begin{abstract}
This article analyzes the German dye business in India before 1947 as an example of expanding German-Indian commercial relationships. German dye manufacturers showed great interest in India's economic potential in the absence of discriminatory tariffs, while Indian elites were interested in non-British Western partners, which could support their struggle for industrial self-reliance. This particular alignment of interests facilitated cooperation and shows that the so-called European experience is more diverse than research has shown so far. The analysis highlights global trading networks beyond the political boundaries of formal empire and offers an alternative perspective on Indian business history, which reveals more competition between multinationals of different origin and more strategic choices available to Indians.
\end{abstract}

Indian business history has become an established field. Business History Review recently published a special issue (2014), edited by Dwijendra Tripathi, which shows the status of research and rightly highlights the many achievements in the field since the mid-1960s, when it first emerged. Business history became established in the Indian context in both academic and professional circles and has added significantly to our understanding of the often ambivalent political and economic relationship between India and Great Britain. However, multinationals "particularly of non-British origin," as Tripathi highlights, have received comparatively little attention so far. ${ }^{1}$

Only recently have scholars extended the scope of the analysis beyond the Indo-British relationship, arguing that the British Empire was a network of interactions with many different and changing centers. The old-fashioned core-periphery model is passé and being replaced with more nuanced descriptions of relationships and encounters of differing scope and impact. Authors are describing links between different colonies within the British Empire as well as the transnational trajectories of goods, ideas, and people. ${ }^{2}$ This echoes Antoinette Burton's plea for repositioning British imperialism in world history without making it into a "teleologically 
hegemonic phenomenon untouched by the threat of competitors or the specter of native resistance from within." As a consequence, the boundaries of empire are becoming more and more porous: Indian connections with China and Japan, with the Americas and Africa, and with different European economies, are figuring more prominently in scholarly research. ${ }^{4}$ Most recently, Sven Beckert has expertly described the truly global network of cotton manufacturing and trade, with major implications for Indian economic and business history but within a larger transnational framework. ${ }^{5}$

Based on similar premises, Japanese economic historians, such as Sugihara Kaoru and Shigeru Akita, make the convincing argument for an evolving relationship between Asian regional economies and the British Empire, acknowledging the autonomous development of the economic region while staying alert to outside influences from Britain and elsewhere in the world economy. Rather than focusing on rivalry alone, these scholars see interdependencies and complementarities between British and East Asian economic interests and trace the relationship over time, as, for example, in the cotton industry, where coarse Asian goods coexisted with fine cottons from Manchester. Japanese industrialization allowed for a trading network with India, which was parallel and not necessarily dependent on the British influence in the region, though Britain responded to the emerging challengers. ${ }^{6}$

There is good reason to include in such discussions the encounters between India and Germany. In political and cultural history, these links have already been a topic of research. Historian Kris Manjapra argues that from the late nineteenth century onward both Germany and India worked toward a common goal: challenging the existing world order under British supremacy. ${ }^{7}$ Indian nationalism and anticolonialism were becoming a prime force in challenging the idea of empire, while German nationalism was a prime force in challenging the idea of an Anglocentric Europe in both the economic and diplomatic realms. The particular alignment of interests from the late nineteenth to the mid-twentieth century facilitated entanglements between India and Germany. These encompassed the field of artistic and intellectual exchanges, as Manjapra impressively documents, but also affected commercial relationships, as I intend to show in this article.

By focusing on German-Indian business encounters I support Tirthankar Roy's argument that the British Empire was much more intertwined with the global economy than historiography has reflected so far. ${ }^{8}$ The imperial framework is clearly of great significance for business in 
India. However, I caution that the strict focus on imperialism has channeled Indian business history toward selected industries and time periods, while simultaneously concealing others. We know most about industries with strong British participation, Anglo-Indian trading networks, and the pre-World War I period, when Britain's economic hegemony in India was less disputed. However, many accounts artificially isolate the British-Indian relationship from the larger global economy and either ignore other competitors or subsume them into overgeneralized concepts, such as the category "European." Comparing different imperial and extraimperial experiences, their encounters and rivalries, will allow for a more nuanced multipolar analysis of the Indian business context.

Narrowly defined, Germany's own colonial history was very brief and ended abruptly in 1918, when it lost its colonies in Africa and the Pacific as a consequence of World War I. However, the desire for colonies and a related revisionism of the colonial experience remained strong in Germany throughout the 1920 s. ${ }^{9}$ Never in its history did Germany have any formal rule on the Indian subcontinent. However, as John Gallagher and Ronald Robinson have eloquently pointed out, formal rule is only one form of imperialism-and not necessarily the most desirable. ${ }^{10}$ Not being a formal imperial power in India did not diminish Germany's interest in this promising market. Gallagher and Robinson's famous formulation "trade with informal control if possible; trade with rule when necessary" stresses that informal control is less exclusive and may be contested over time, for example, by foreign challengers.

From the late nineteenth century onward, Germany attempted to become such an economic challenger to Great Britain, with varying success. ${ }^{11}$ Like their counterparts from Switzerland, Japan, France, and possibly elsewhere, German businesspeople were able to present themselves as outsiders of empire, facilitating their interactions with nationalistic Indians. ${ }^{12}$ In addition, German businesspeople over time learned that in particular their rivalry with Great Britain in Europe was well-received in India. Indians were open to the idea of Germany as an alternative European power, which could potentially support India's economic development and political independence. After World War I the idea that "the enemy of my enemy is my friend" created an environment particularly conducive to a variety of entanglements. During both wars, this fortuitous alignment of interests led to military cooperation between the German government and different groups of Indian nationalists. ${ }^{13}$ The business relationship between Germany and India has not yet received similar attention. ${ }^{14}$ 
The relevance of extraimperial competitors varies starkly among different industries. While British-Indian power struggles shaped the development of the much-discussed textile industry significantly, scholars who have focused on bazaar goods (such as sewing machines, typewriters, gramophones, and bicycles) find much more global competition. ${ }^{15}$ For the Indian steel industry, Aparajith Ramnath also convincingly demonstrates the influence of U.S. and German experts on the development of local industry. ${ }^{16}$ In this article I will focus on synthetic dye manufacturing, an industry that is particularly well suited for this discussion, for two primary reasons: First, prior to World War I, German dye manufacturers enjoyed a virtual monopoly. In the interwar years the fierce struggle over foreign markets (e.g., India) exemplifies how international competition stretched into imperial markets, where the political economy allowed for it. Second, during the war and interwar years, manufacturers in the dyestuff industry engaged in multiple forms of collaboration typical for this time period. ${ }^{17}$ These industry agreements make research "beyond the nation state," as is often claimed in transnational history, or beyond the boundaries of empire, necessary. ${ }^{18}$ The dyestuff industry is of great significance to the Indian economy because it supplied the textile industry, which was growing quickly and was central to emerging debates on Indian nationalism. Surprisingly, the extensive monographs on German dye companies only mention India as the largest export market for dyes after World War I (together with China) but do not provide any detail on business practices or local market challenges. ${ }^{19}$

Adding the German perspective has the practical advantage of making new sources available to scholars of Indian business history. ${ }^{20}$ The primary sources for this article come from German corporate, federal, and Foreign Office archives, all of which have scarcely been used in Indian business history. The finding aids of the Bayer Archives in Leverkusen, the federal Bundesarchiv, and Foreign Office archives (Politisches Archiv) helped identify sources on German business in India. After having established a chronology of events, I also consulted archival materials from the India Office Records at the British Library, the U.S. national archives, and the West Bengal State Archives. The reliance on multiple perspectives counteracts some of the biases in the source material, which was archived primarily in different Western countries, and facilitates greater contextualization. ${ }^{21} \mathrm{My}$ approach was inductive and is based on close reading of source material composed primarily of business, government and private correspondence, accounting files, travel and annual reports, photographs, and newspaper articles. 
This article is structured chronologically, from the introduction of synthetic dyes into India in the 1870 s to the expulsion of German business from India during World War II. The analysis combines descriptions of the business and the industry environment in the context of a changing political economy. For the period up to World War I the empirical analysis focuses on the biggest importer of dyes into India, the chemical firm Bayer, which served as a model for other German dye companies, notably Hoechst and BASF. After 1925, Interessengemeinschaft Farben (hereafter, I.G. Farben), created by a merger of these major German dye manufacturers, organized the India business of these companies jointly.

\section{German Dyes in India before World War I}

The production and use of dyestuffs is an ancient art. Archaeological evidence shows that in India dyeing was a widespread activity as early as the third millennium BCE. Dye substances included plant juices and animal and mineral substances. The most commonly used dyes were madder, lac, cochineal, and kermes for producing red; turmeric, safflower, saffron, and mineral orpiment for yellow; indigo for blue; and gall black for black. ${ }^{22}$

Industrially produced dyes entered the market in the mid-nineteenth century. In the late 1850s, aniline dyes, derived from coal tar, first became available. The German chemical industry was a first mover in the business of synthesizing the colorants of the main natural dyes. Around 1870, it began offering synthesized alizarin, the colorant of the important red dyestuff madder, and from the 1890s it also offered synthesized indigo from aromatic hydrocarbons. ${ }^{23}$ Synthetic dyes increasingly replaced the majority of natural dyes. However, the eventual success of artificial dyes cannot be explained by price differences alone, as historian Alexander Engel argues, because these were negligible prior to World War I. Instead, artificial dyes allowed for a greater standardization of the dyeing result and a greater variety of dyes, and the manufacturers had a superior distribution model. ${ }^{24}$

For indigo in particular, the transition from natural to artificial dyes equaled a reversal of previous trade structures: natural indigo in the nineteenth century originated primarily in India and was brought to market by British planters. With the change to synthetic indigo, India lost its position as a major exporter to Germany. ${ }^{25}$ Three-fourths of all synthetic dyes originated within Germany just before World War I; another eighth were made using intermediates imported from 
Germany, so that an estimated 88 percent of world production was ultimately controlled by Germany. ${ }^{26}$ German manufacturers profited from a supportive environment, including a welldeveloped system of higher education in chemistry, an abundant supply of the raw material coal, a system of industrial laboratories supporting the development of patentable products, and a patent law that protected only production processes and not particular goods, thus promoting innovation more effectively than French or British legislation. ${ }^{27}$

For the German dye industry, India was the fifth-largest market by weight-after the United States, China, Great Britain, and Austria-Hungary - and the fourth-largest market by value, after China, Great Britain, and the United States (Table 1) ${ }^{28}$ The British-Indian statistics show that about three-fourths of all imported synthetic dyes came from Germany. Belgium, the United Kingdom, and Switzerland supplied the remainder, sometimes through re-exports. ${ }^{29}$ The majority of the imports were cotton dyes for the large cotton mills. Most dye imports went to the harbor of Bombay (now Mumbai), which was the chief distributing center for the trade due to the large number of cotton mills in the Bombay Presidency. ${ }^{30}$

The major German players in the synthetic dyestuff industry were Bayer (founded in 1863), Hoechst (also 1863), and BASF (1865). The case of Bayer is exemplary of the business model of German dyestuff firms in India. Bayer's dyes first came to India in the 1870s and 1880s through occasional deliveries by import-export houses, such as Ullmann Hirschhorn \& Co., Bell Brandenburg \& Co., and long-established British trading companies like Graham \& Co. Founded in 1784 in Glasgow, Graham was an active India trader and one of the largest importers of Lancashire textiles into India. ${ }^{31}$ In the 1880 s, Bayer managers, through their business in Great Britain, became acquainted with Lancashire businessman James Kerr, who had spent many years as a partner in the import firm Kerr, Tarruck \& Co. in Calcutta (now Kolkata). Together with Kerr, who knew the Indian dye market intimately, Bayer established its first consignment warehouse in India, in $1888 .{ }^{32}$ Shortly thereafter, the company sent Henry Böttinger to India to study the opportunities for a more systematic business. Böttinger had been a managing director of Bayer since 1882 and was married to one of the founder's five daughters. Manager Carl Rumpff, who had overseen much of the India business and was another of the founder's sons-inlaw, wrote an extensive memorandum on the potential of the Indian market, the local conditions, and the role of the Parsee ethnic group as intermediaries. Particularly for the marketing of dyes, 
Rumpff insisted on hiring a Parsee who could manage the introduction of labels and understood the local conditions. ${ }^{33}$

In addition, Bayer established a relationship with the Indian chemist Tribhuvandas Kalyandas Gajjar. Gajjar had a chemistry degree from Elphinstone College in Bombay and had studied the indigenous dyeing and printing industry in much detail. In 1890, he was asked by the local ruler of the state of Baroda, Sayyaji Rao Gaekwar, to establish an industrial school to train students for the development of local industry. The "Kala Bhavan" was composed of six schools, including the "School of Dyeing and Chemical Technology," and was focused on applied sciences and the creation of intimate links to industry. Training in chemical technology included dyeing and bleaching, calico printing, organic chemistry, and the chemistry of coal tar. ${ }^{34}$ It was Gajjar who first suggested to Bayer "to train students and instruct native dyers in the use of their [German] dyes if they desired India to become one of their great customers." 35 In response, Bayer financially supported the establishment of a laboratory in Surat and appointed Gajjar the firm's consulting chemist. The German firm also sent (and funded) several experts to the school, such as a technician named Schuhmacher and a professor of chemical technology, Dr. Ehrhard. Training centers for dyers were opened in Ahmedabad, Delhi, Cawnpore, and Amritsar under Gajjar's supervision. Many of the students were later employed by Bayer in its India business. ${ }^{36}$

In 1892, Bayer hired Charles J. Vernon (Figure 1), a former employee of the British Graham \& Co., as its managing director in Bombay. Kaba Virchand (Figure 2), a Parsee and a former employee of an Indian dye company, was engaged to organize the local sales activities. In 1896 the agency formerly called Vernon was renamed "Bayer \& Co. Ltd." and registered under the Indian Companies Act of 1882. It was Bayer's first wholly owned subsidiary in Asia. ${ }^{37}$ Between 1900 and 1913 Bayer's sales in India increased more than sevenfold, from RM 320,199 to RM 2,451,647 (approximately US\$76,274 to US\$584,004), generated in a total of sixteen offices. ${ }^{38}$ The other German dye manufacturers showed similarly positive results in the decade prior to World War I and increased their dye exports to India (as well as China) by leaps and bounds. ${ }^{39}$ The business success of the German dyestuff manufacturers was the result of their monopolistic position. A well-functioning sales organization and early contacts with local scientists and traders added to the firms' good standing in India. All larger German dye manufacturers had their main depots with laboratories and technical staff in Bombay as well as smaller depots in the important dyestuff-selling cities. The dyestuffs were shipped in bulk and 
then diluted to the required strengths in Bombay. The German manufacturers also invested in training and developed local salesmen and demonstrators. ${ }^{40}$ These localization efforts were appreciated by Indian buyers, particularly in the context of the increasingly politicized textile industry.

In the textile industry, the early Indian independence movement and the struggle for industrial self-reliance became influential around the turn of the century. The nationalist swadeshi movement - swadeshi meaning "of/from one's own country" - called on Indians to consume indigenous goods rather than imported ones, claiming that foreign imports stalled the national economic development. Swadeshi ideas had circulated for a while but the movement experienced a major push in the wake of the campaign against the partition of Bengal province that began in $1903 .^{41}$ The Viceroy of India, Lord Curzon, decided to partition Bengal, which he allegedly considered too large for effective governance. Lord Curzon's plans were met with deep resentment because they were seen as restraining the growing power of articulate Bengali Hindus. ${ }^{42}$ The growing nationalistic sentiment, first in Bengal, then throughout the country, helped German businesses improve their competitive position vis-à-vis British firms. Although counterintuitive, the Indian nationalist movement-while openly calling for a boycott of "foreign" products - enabled rather than restricted cooperation with German firms. Activists in the early twentieth century began arguing that as long as India was dependent on imports, they should come from countries other than Britain. The nationalist Sri Aurobindo distinguished between economic and political boycott with the latter following the political agenda of India's independence by all available means, including cooperation with other Western competitors. "Why should we take revenge upon America or Germany for the oppression caused to us by the people of Britain?" he asked in a speech on January 30, 1908, explaining, "There is a political reason ... for the boycott of British goods; it is to make the brethren of our oppressors feel the pinch." 43 Weakening England's economic hegemony could be achieved by different means, one of which was cooperation with selected Western competitors.

This line of thinking created a pro-German environment in nationalistic circles. Charles Stevenson-Moore, inspector-general of the Police of Bengal, confirmed, "A distinction is being made between English and Continental goods, adverse to the former." He even reported a case of fraud in which English goods were being sold successfully as "Made in Germany." " Ironically, the label "Made in Germany" had been forcefully introduced by Great Britain in the 
Merchandise Marks Act of 1887 to distinguish high-quality British goods from cheap German alternatives. ${ }^{45}$ It was implemented in India in the Indian Merchandise Marks Act of 1889, which stipulated that goods had to be marked with their country of manufacture "to protect the consumer from being induced to purchase inferior foreign goods under the impression that they were manufactured in England." ${ }^{46}$ The changes in the political economy, however, gave new meaning to the label and allowed Indians to choose or avoid products based on their origin.

Turning Point: World War I and the Postwar Years

At the outbreak of World War I, German assets in India were expropriated under a "Trading with the Enemy Act" modeled on similar legislation in Britain. Britain determined India's foreign policy, and the Governor-General and Viceroy of India proclaimed India to be at war with Britain's enemies. Hostile foreigners or firms were forbidden from trading unless licensed by the government of India. The definition of a hostile firm was comprehensive, including "any company, firm, association, or body of individuals incorporated or not, of which any member or officer is a hostile foreigner." 47 By January 1916, 114 enemy firms were in the process of liquidation and seventy-nine were trading under control. ${ }^{48}$ Bayer's business, officially incorporated under Indian law, was identified as an enemy firm without hesitation and dissolved in November 1916. The German employees present in India were interned in the prison camp Ahmednagar, in the western part of India. A total of 203 Germans and forty-six Austrians were behind barbed wire in November 1915 whereas several hundreds were under the control of the civil authorities but not interned. ${ }^{49}$ In addition to the direct expropriation of German assets, British wartime protectionism also triggered companies based in neutral countries, such as Switzerland, to cut their many connections to Germany. ${ }^{50}$

Although India officially supported Great Britain during the war, Germany's political interest in the revolutionary potential of the country also increased, and Germany actively engaged in organizing anti-imperial outbreaks in India. ${ }^{51}$ The German government supported and funded Indian revolutionaries, such as the Ghadar movement of immigrants, mainly Punjabi, in the United States, which organized disturbances in India and eventually attempted an armed uprising against the British. The scheme failed and many of the agitators were put on trial in both 
India (the Lahore Conspiracy trial of 1915) and the United States (the Hindu-German conspiracy case of 1917-1918 in San Francisco). ${ }^{52}$

With the outbreak of the war, the total import of dyes into India fell abruptly to one-third of prewar amounts. ${ }^{53}$ Those dyes remaining in the country, or making their way there during the war, were sold at auction. While in most industries British, American, and Japanese competitors quickly filled in the voids that the Germans had left, they did not have the production capacity to meet the demand for dyes. ${ }^{54}$ By 1916 , the scarcity was so acute that prices increased sharply. The Times of India reported on a Madras (now Chennai)-based auction in July 1916: "Never there was such a large crowd of industrialists, not even in any of the Industrial Conferences in India ... as there was yesterday at the auction." The price of one keg of Alizarine (diluted to 16 percent), which had cost Rs 35 (or US\$11) before the war, went for Rs 1,000 (or US\$314) on average, with the highest price of the day reaching Rs 1,400 (or US\$440), or forty times the original price. ${ }^{55}$ In Cawnpore, the shortage of dyes was obvious to even the casual observer "by the remarkable absence during the recent Holi festival of colour throwing," a custom for which dry powder and colored water were traditionally used. ${ }^{56}$ Over the following years, Germany's competitors supplied increasingly greater quantities of dyestuffs. While the German manufacturers had provided their dyes to both textile mills and bazaars, the late movers followed a division of labor: British dyes were sold primarily to factories, while American and to a lesser extent Japanese dyes went to the bazaar segment. ${ }^{57}$

During the war the interest of the German chemical industry shifted from dyes to chemical weapons and explosives. The pressure of wartime also precipitated industrial cooperation. In 1916, eight German dyestuff firms entered into a pooling agreement, the socalled community of interest (Interessengemeinschaft, or I.G.), which continued after the war. ${ }^{58}$ Because the German chemical industry had supplied large amounts of weapons, after the end of the war the victorious Allies established a system to monitor and control it. In addition, the Treaty of Versailles (Annex VI) granted the Allied Powers the right to request up to 50 percent of all German dye stocks as a reparation payment as well as 25 percent of the ongoing dye production every six months until 1925 . The treaty also included a number of technology transfer provisions, granting the Allies free use of German patents, access to technology, and factory visits. By the early 1920s, most relevant chemical technology had passed into the hands of Great Britain and France. ${ }^{59}$ However, the industrial capacity of Germany's chemical industry remained 
largely intact and many of the wartime products found peacetime applications - as intermediates in dye production, among others. ${ }^{60}$

In India, after the end of the war, many Indians expected Britain to reward them for their loyalty with a greater voice in their own government. When this did not happen, members of the Indian National Congress (INC), the predominant public organization of independence activists, demanded that President Wilson's principle of self-determination be applied to India. ${ }^{61}$ In the aftermath of Versailles, India became a member of the League of Nations; however, those who hoped that this "external self-determination" would eventually lead to "internal selfdetermination"-i.e., self-government-were disappointed. The Government of India Act of 1919 instituted the principle of diarchy in the British-Indian government. Indian ministers were chosen by the British governor from the elected members of the province's legislature and given responsibility over a few selected areas of government, such as education and public health. Disappointingly to Indian nationalists, all other government business remained under the control of the British Viceroy, including the key areas of defense, foreign affairs, and communications. ${ }^{62}$ As part of the reform, India obtained for the first time a limited measure of fiscal autonomy. The British government would not interfere in India's fiscal policy as long as there was complete agreement between the government of India and the legislature. The government of India, however, was responsible to the British government and made sure that British commercial interests were fully taken into account. The first Indian Fiscal Commission, in 1921, generally recommended a protectionist policy, to spur India's industrial development. It discussed but ultimately rejected the idea of giving preferential treatment to British dyes in India, because they were considered of inferior quality. Not allowing Indian textile mills to buy the best available dyes would handicap their competitiveness. ${ }^{63}$ Moreover, the Calcutta-based economics professor Pramathanath Banerjea, an expert on fiscal policy, argued that since India had no dye industry of its own there was little to be gained from protectionism. "Protection should begin only when a particular industry is fully equipped to take advantage of it," he argued. ${ }^{64}$

Dissatisfied with the reforms of the Government of India Act, the INC approved a "NonCooperation Resolution" in December 1920, suggesting among other measures a boycott of foreign goods. This resolution owed much to Mahatma Gandhi's philosophy. It insisted on the inextricable link between indigenous goods and self-government and argued that only a reformed lifestyle, symbolically captured in the wearing of khadi, an uncolored homespun would lead to 
the necessary radical changes. Swadeshi, in this Gandhian sense, meant the complete rejection of all foreign products. However, there was never a consensus on this radical, almost utopian vision within the INC. Gandhi's critics ridiculed him for refusing to embrace industrialism, and he increasingly (not least under the pressure of Indian industrialists who supported the movement financially) softened his position. By 1930, the distinction between handmade and industrial products, central to Gandhi's thinking, had been largely set aside. The one between indigenous and foreign products remained but was lacking in definitional clarity. Goods manufactured in India by foreign companies, and goods from countries other than Great Britain, were never explicitly but often silently excluded from boycotts. "By 1930," historian Lisa Trivedi argues, "swadeshi was a term configured broadly enough to cover a range of economic and political processes." 65

This opened up opportunities for non-British firms once again. Germans were forbidden from traveling to India until August 31, 1925. However, the demand for dyes in India remained great, and so entrepreneurial Indians took the initiative and visited German companies at home to pave the way for commercial cooperation. In 1921 Bayer met with the chemist J. C. Das Gupta of Calcutta at the company's headquarters in Leverkusen. Das Gupta had studied in Germany and worked for the Swiss company Hoffmann-La Roche. He represented several Indian firms eager to establish contacts with dye manufacturers and presented his ideas on how cooperation could be organized. ${ }^{66}$

To circumvent the travel restrictions, German dye manufacturers also reverted to “cloaking," i.e., disguising German ownership of firms and commercial transactions. ${ }^{67}$ Bayer rebuilt its India business with the support of the Milan-based firm Iridiscente, which in turn cooperated with G. Gorio Ltd., an Italian firm with an office in Bombay. ${ }^{68}$ In 1921, Bayer sent its employee Giulio Gut, a native German who had acquired Italian citizenship as a resident of Asmara, Eritrea, to Bombay to support the new business. ${ }^{69}$

The travel restrictions were eventually abolished in $1925 .{ }^{70}$ In December 1925, Bayer and five other German chemical manufacturers, including the major players BASF and Hoechst, built on their previous cooperation to form I.G. Farben, creating a chemical giant that produced 90 percent of the world's dyes. ${ }^{71}$ The newly founded I.G. Farben ended Bayer's relationship with Gorio in 1926 and signed a sole-importer contract with the Dutch trading company Havero, which was to sell all I.G. Farben products in India. In addition to this official contract, Havero 
and I.G. Farben had a complicated secret agreement according to which two Dutch companies, Overzee and Unitas, held 100 percent of the shares of Havero and promised to oversee Havero's complete compliance with I.G. Farben's wishes. ${ }^{72}$ This elaborate cloaking continued to disguise German ownership for two primary reasons: First, the complete loss of assets in World War I had put political risk management on the company's agenda. ${ }^{73}$ Second, in 1922 Indian tax law first made room for the possibility of taxing foreign manufacturers based on their "Manufacturer's Profit," meaning all worldwide profits, and authorities increasingly applied this law more rigidly. ${ }^{74}$ As Havero was registered under Indian law, I.G. Farben hoped to avoid paying an additional tax as a foreign company.

Dyes remained scarce in the first half of the 1920s, but after the occupation of the Ruhr region by the French in 1923, production once again increased, eventually leading to an oversupply. ${ }^{75}$ All dye-producing countries manufactured more dyes than their home markets required. They also established protective barriers, including tariffs, subsidies, and privileges for national producers, which allowed the home industry to fulfill the lion's share of internal demand. As a result all manufacturers competed keenly for the accessible export markets, most importantly for the nonproducing countries China and India. ${ }^{76}$

In India, the German dye firms regained their lost market share quickly, not least due to their increased production capacity and well-functioning organization. The business remained split into factory and bazaar segments; the factory business was done in selected large centers, where the majority of the cotton mills were located, such as Bombay, Ahmedabad, Cawnpore, Calcutta, and Bangalore. Mills bought primarily sulphur black for coarse cloth, and the majority operated in-house dyeing departments. In Bombay, they also sometimes outsourced the dyeing process to contractors. Havero sold dyes directly to the mills or their contractors and to that end visited the factories regularly. ${ }^{77}$ Due to the close contact with these large customers and a better understanding of their needs, Havero managed to successfully introduce the I.G. Farben's more expensive fast colors, a market that was growing quickly. ${ }^{78}$

In the bazaar trade, Havero (representing I.G. Farben) marketed its dyes through sixteen Indian distributors. The dyes were delivered on consignment but for a cash deposit, on which the distributor received a monthly interest of 6 percent. Sales prices were fixed by Havero, and the sellers received commissions and reported their sales on a daily basis. Prior to the collaboration in the I.G., each German firm had employed its own distributors, with long-term agreements 
making them unavailable to competitors. Consequently, there was a significant overlap between the regional responsibilities and no seller had exclusive rights to any territory. Visiting India, Carl Duisberg, chairman of the supervisory board of I.G. Farben, remarked that "most of them are rich orthodox merchants with little knowledge of dyes." ${ }^{.79}$ Controlling the Indian distributors in the bazaar segment was almost impossible and created a series of principal-agent conflicts, frequently based on the generous discounts that distributors gave in the competitive market space.

The Indian distributors sold the dyes in one- or half-pound tins to both end consumers and intermediaries, with the latter reselling the product out of open tins in extremely small quantities, often measured in spoons. The colors were diluted so that a minimum purchase of half a pound was affordable. Larger quantities, up to 112 pounds, could be sold to local dye houses. Trademarks - pictorial labels in particular-were very valuable in the multilingual Indian context with its high rates of illiteracy. The Dutch Havero assigned great importance to the various trademarks of the I.G. firms but also, remarkably, saw much value in the label "Made in Germany," which, according to leading managers, was recognized and appreciated. ${ }^{80}$ Similarly, the German consul in India observed "great sympathy for German products," while the Foreign Office in Berlin heard with interest about a Bombay trader of machinery whose fixtures were rejected in a factory in Ahmedabad because they were not visibly marked "Made in Germany." 81 I.G. Farben's market share increased in the 1920s. In 1920-1921, still recovering from the war, the companies of the I.G. Farben together had accounted for 34 percent of all dye imports to India. In 1929-1930 they supplied 70 percent of all dyes, making India I.G. Farben's fourthlargest foreign market, with more than Rs 19 million in sales (US\$6.86 million). At the same time the British market share declined from 33 to 7.4 percent, a loss attributed to anti-British sentiment in the country. ${ }^{82}$

The Civil Disobedience Movement (1930-1932) increased the impact and magnitude of anti-imperial boycotts. On March 12, 1930, Gandhi and some followers began their famous salt march to Dandi, a coastal village in Gujarat, to protest the Salt Law. Boycotts of foreign cotton piece goods were ubiquitous in those years. ${ }^{83}$ The German Foreign Office observed the development closely; it encouraged German firms to be sensitive to Indian sentiments and to avoid any racial tactlessness, such as calling Indian trading partners "natives," a label considered pejorative ${ }^{84}$ In a confidential report of 1930, a Foreign Office official opined that anti-British 
sentiment could be expected to persist given the collision of the "racial arrogance of the English" with the newfound confidence of the Indian population. ${ }^{85}$

In January 1930, the German, Swiss (i.e., Swiss I.G. composed of Ciba, Sondoz, and Geigy), and French (Compagnie des Matières Colorantes, or Kuhlmann) dyestuff makers joined forces in a cartel. Negotiations with the British ICI had been ongoing since the mid-1920s. ICI wanted the cartel to agree to a quota based on the weight of dyestuffs sold by all makers within the British Empire. This was an unusual demand for ICI, since in other product lines the British manufacturer insisted on exclusive rights to the British Empire. However, in India the German competitors were well established and there was less demand for some of the more sophisticated and profitable dyes that the British supplied. The continental cartel eventually agreed to the quota and thus granted ICI a complementary right to sell in Swiss and German markets, where its more expensive dyes had a larger market, beginning in 1932. The cartel was intended to last for the atypically long period of thirty-six years. It granted the I.G. Farben a quota of 65.5 percent of world export sales and ICI 8.43 percent. ${ }^{86}$ In 1933, two-thirds of the world's dye market (by value) was controlled by the cartel, which competed with U.S. (19.6 percent), Russian (4.6 percent), and Japanese (3.7 percent) manufacturers as well as some British and Dutch independents. ${ }^{87}$

Despite this collaboration, export activities became increasingly more complicated and politicized. The Great Depression created grave problems in India as agricultural prices plummeted, and orthodox financial and monetary policies aggravated the situation. The government resorted to additional taxation, levying a general surcharge of 25 percent on all existing taxes. Import duties on a number of products were increased; an import duty on dyes was suggested for the first time but heavily criticized. Mill owners insisted that raw materials and machinery, needed for the development of India's own industry, should be allowed into the country without restrictions and from any foreign country. ${ }^{88}$ The Taxation Act of 1934 nevertheless introduced a 10 percent tax on dyes, applicable to all foreign dyes, from both within and outside the British Empire. ${ }^{89}$ Since there was no domestic dye industry, the tax did not change the competitive dynamics between the foreign manufacturers. International monetary policy, however, did. In 1931, the British pound departed from the gold standard, while the Reichsmark remained linked to gold. Consequently, the Indian rupee depreciated relative to the Reichsmark, making exports less profitable. The German government, in desperate need of 
foreign currency exchange, expanded its export subsidies and increased state control of imports and exports. ${ }^{90}$

Finally, implementation of the cartel was not without challenges. While the place of supply rules could easily be implemented in the mill business, I.G. Farben had less control over the bazaar business, which involved all cartel firms via large Indian merchants. It was therefore necessary to make arrangements for local cartels. From 1931 onward, the firms of the cartel met weekly to discuss the implementation of the cartel agreements in India. By 1938, they had agreed on rigid local conditions, including minimum net prices, terms of sales, the maximum number of local distributors, and the maximum commission to be granted to them (between 7.5 and 12 percent, depending on the product). However, making sure the theoretical guidelines were followed in the Indian bazaar segment remained difficult. ${ }^{91}$

\section{India and Nazi Germany}

Thanks to the cartel agreement and local negotiations, I.G. Farben continued to increase its profits in India (Table 2). The firm profited from its established trademarks, which Havero actively pushed throughout the 1930s, while other cartel firms were content to supply their dyes in bulk and have them repackaged and rebranded by the approximately 150 local "mixers/packagers" throughout the country. ${ }^{92}$ The rise to power of the Nazis in 1933 did not at first cause major disruptions in German-Indian business relations; however, Adolf Hitler frequently and publicly expressed his disapproval of the Indian independence movement. Select Indian industrialists voiced their concerns about this to German business partners, who tried to downplay Hitler's comments. ${ }^{93}$

I.G. Farben's top management continued to be excited about the potential for their business in the context of the Indian nationalist movement. The INC, while still encompassing diverse and conflicting interest groups, evolved into a more organized party after the mid-1930s and gained greater concessions from the British government. The 1935 constitution introduced a larger measure of autonomy to the provinces of British India, direct elections, and more elected Indian representatives, while retaining the British right to suspend government, among other limitations. Due to its limitations and to the fact that it was drafted without Indian participation, the law was met with little enthusiasm. The INC nevertheless participated in the provincial 
elections and scored impressive victories, including an absolute majority in six of the eleven provinces in 1937. The majority of the Indian business elite showed some support for the INC, despite pockets of resistance and fear that Gandhi's hostility towards modern industry might be reflected in politics. ${ }^{94}$ Despite diverging opinions within the INC, however, it was obvious to the German observers that greater Indian participation in both politics and economics was not only inevitable but also potentially beneficial to Germany.

In 1937-1938, Anton Reithinger, chief of I.G. Farben's Macroeconomic Department, met with Indian nationalists, Indian industrialists, and British administrators in India. Reithinger observed with delight that both British and Indian elites were favorable to India's economic development — the former to secure peace, the latter to achieve independence — so that Germans would not be forced to pick sides. In both Bengal and the United Provinces, he observed that Indians tried to exclude the British from economic transactions and actively sought out German, Japanese, and Italian alternatives. Moreover, the increasing number of newly appointed Indian civil servants in administrative positions often bought German products as a way of supporting their political agenda. In provinces with INC governments, purchasing policies of government departments were reviewed with the aim of avoiding British goods. Reithinger strongly advocated strategic neutrality: not opposing British rule but capitalizing on "the Indians' wish to include other nations of the world in the development of their country." He also saw race as a major issue and considered it a great advantage that "our people do not represent a 'superior/dominating people' [übergeordnetes Herrenvolk] but can rather act as friends on the same societal and personal level." ${ }^{95}$ This advantage could be exploited even more, he argued, if I.G. Farben decided to end its cooperation with Havero and incorporate under Indian law as well as hiring Indian representatives in leading positions-a strategy also pursued by other German firms at the time. ${ }^{96}$

Following Reithinger's suggestion, I.G. Farben incorporated locally that same year, 1938, and cut all visible ties to the German I.G. to protect the new organization from political risks, most importantly taxes. It also separated the dye business from other product lines, such as chemicals and Agfa (photographical products). Finally, the new organization was designed to be more open to Indians and the nationalistic movement. The German managers discussed Gandhi's definition of a swadeshi company as any firm "whose control, direction and management . . . are in Indian hands." Gandhi declared he had no objection to foreign capital or labor that was "used 
in the interests of India" and under Indian control. ${ }^{97}$ The German managers determined that it would be impossible for them to fulfill these criteria fully. However, they banked on a more flexible application of the principle and hoped that Indian participation in management would count in their favor. They decided that the board of directors should have at least one Indian member, who would be financially rewarded for his services, even if he decided not to take part in meetings. ${ }^{98}$

Unexpectedly, the reorganization of I.G. Farben's India business triggered the interest of the German government. The Nazi Foreign Organization, which was responsible for Germans abroad and the approximately six hundred Nazi subgroups outside of Germany, interrogated I.G. Farben about the racial composition of its workforce in India. ${ }^{99} \mathrm{~A}$ total of 909 employees worked for I.G. Farben in India in 1937-1938, of whom seventy-six (8 percent) were Europeans. The dye business alone employed thirty-seven Europeans, of which twenty-four were German, four Swiss, two Italian, two Czech, and one each British, Dutch, Norwegian, Danish, and "stateless." The international diversity of this workforce was a conscious choice and a strategy intended to mitigate political risks and circumvent potential nationality-based restrictions. ${ }^{100}$ The Nazi Foreign Organization requested the firing of all Jewish employees and proof of "Aryan" descent for all others. I.G. Farben hesitated, knowing this policy would have consequences for its image in India. ${ }^{101}$ There was a significant Jewish population in the country, largely concentrated in the Bombay Presidency, where I.G. conducted most of its business. ${ }^{102}$ The Nazi regime had been a frequent topic in the Indian press since 1933, where it received both criticism and support. Some Indian journalists defended the Nazi racial policies; some even highlighted the alleged joint heritage of Germans and Indians in an ill-defined "Aryan" community. ${ }^{103}$ However, press reports about the abuse of Indians in Germany as early as 1933 fueled criticism. An Indian correspondent reported in much detail about the humiliating and violent treatment he received from SA storm troopers in Berlin. ${ }^{104}$ While early calls by Jewish organizations for a boycott of German products showed little effect, a speech by Hitler in January 1936 in Munich triggered massive protests. ${ }^{105}$ Hitler claimed it was "the calling of the white race to dominate over colored people"- a statement that infuriated the Indian public. In response, Indians demonstrated in front of the German consulate and the mayor of Bombay called for a boycott of German products. ${ }^{106}$ An article in the Jewish Tribune said, "Indians who before this tirade were not concerned in any way with the treatment of the Jewish people in Germany continued to be one of Hitlerland's best 
customers. . . However, the Fuhrer has exceeded himself and it is not surprising that selfrespecting Indians have paused to think for themselves."

I.G. Farben now encountered a much more hostile climate, so the call for letting go of non-Aryan employees posed not only a human resources but also a significant public relations quandary. Nevertheless, the firm eventually dismissed its Jewish employees, making a cynical public statement that doing so was in the best interest of those employees, as they could avoid business trips to Germany in the new political context. Havero manager Geo Kreczmer advised all employees to accept this explanation given that "it would be stupid to try and deny the resignation of all non-Aryans."108 However, I.G. silently bypassed the question of whether Indians should be considered "Aryan." Pressed once again for "proof of aryanization" of its employees, in December 1938, manager Oswald Urchs replied that Indian press coverage of Germany's latest laws against Jews had been so negative that an official request for any such proof would only make the position of German firms more difficult. ${ }^{109}$ This statement by Urchs, who was a known Nazi supporter, showed greater concern for commercial success than for racial policy.

World War II, which began on September 1, 1939, abruptly ended German business activity in India. Approximately six hundred German men, primarily businesspeople and missionaries, were confined in Indian internment camps. ${ }^{110}$ German assets were once again expropriated and all Indian workers let go. Colonial intelligence reports noted that German firms showed their Indian employees great respect and compensated them generously for losing their jobs. "They [the Indian employees] are consequently inclined to regard the Nazi regime with favour and to speak well of it among their friends, a fact which has propaganda value," claimed one colonial intelligence report. ${ }^{111}$ Nazi propaganda was widespread in India just before and during World War II and generally a concern to British intelligence. Germany organized radio broadcasts in India in twenty-two languages. After December 1940 the frequency was increased to at least one fifteen-minute broadcast daily. ${ }^{112}$ While the German government once again increased political cooperation with Indian nationalists, most notably Subhas Chandra Bose, the German companies focused their attention on supporting their employees in Indian internment and planning a potential postwar reentry into India, when they hoped to once again count on Indian cooperation. $^{113}$ 


\section{Conclusion}

Indian business history so far has focused strongly on the Indo-British economic and political relationship. As a consequence it is biased toward industries with strong British participation, such as the textile industry, and time periods when Britain's economic dominance was least disputed, such as the pre-World War I period. Recently, several scholars have criticized the tendency in historiography to artificially isolate the British-Indian relationship from the larger global economy. Christof Dejung (on Swiss business) and Sugihara Kaoru and Shigeru Akita (on Japanese business) have triggered a new interest in actors from outside the British Empire, who increasingly, over the course of the twentieth century, turned into competitors of Britain in the Indian business environment.

The case of the German dye industry fits into this framework and makes a number of additional points: The experience of German businesspeople resembles that of their Swiss and Japanese counterparts. Over time the Germans realized that one of their biggest advantages in the context of Indian nationalism was their status as not only "outsiders" but also allegedly outspoken rivals of the British and challengers to the British economic hegemony. The "Made in Germany" label and any support of India's industrial development (e.g., exchange of businesspeople and scientists, education) improved Germany's position with Indian nationalists. Without having to take an explicit position vis-à-vis the question of Indian independence, German firms could count on the support of Indian nationalists who provided local knowledge and relationships that enabled the German late industrializers to catch up to their British competitors. The case of the German dye industry thus points to the important changes that late industrializing countries triggered in the dynamics of world trade. It also restores to India its due agency and highlights the variety of strategic choices available to Indian business partners. The categories "Western" business or "European" business - much used in Indian business historyare of little practical use in describing these relationships.

The dyestuff industry is of particular interest to this field of research for three primary reasons: Firstly, dyes are intermediary products of great relevance to India's industrial development, and therefore Indians actively sought their unhindered import into the country. The case shows how growing Indian participation in economic matters translated into opportunities for business from outside of the British Empire. Secondly, dyes and textiles are complementary 
products. While the importance of the textile industry in the Indian context is uncontested, scholars have so far had little to say about dyes, not least because they do not fit into the dominant narrative of imperial history, which is first and foremost a British-Indian history. Thirdly, beginning in the interwar years, the dyestuff industry engaged in multiple forms of collaboration and industry agreements, which regulated a significant part of the dye import into India. These agreements, which are independent of the economic relationships within the British Empire, make it necessary to look beyond the political unit toward competitive dynamics in global trade.

The case of German dyes also highlights some of the challenges of building a business in India. Principal-agent problems with local intermediaries, marketing, and the lack of local knowledge and connections in India were all obstacles for business. In addition to these challenges, typical for internationally active companies, home-country politics also strained the crucial relationship with Indians. Germany's choice to keep its currency pegged to gold, while the British pound and the Indian rupee left the gold standard, made exports less profitable. Moreover, Nazi policy after 1933 forced German businesspeople into a defensive position, in particular concerning their position on race. Though trying to maintain an air of neutrality, managers experienced the German government's increasing involvement in day-to-day business, and their pushback was hesitant at best. In the highly politicized context of interwar India, managing home- and host-country politics, including questions of race and nationality, moved up on the agenda of the dye companies, and their eagerly guarded neutrality towards India's independence movement was increasingly contested.

World War II and the expropriation of German business in India, similar to the events during World War I, yet again put a temporary end to the German-Indian business relationship. German chemical companies returned to the Indian market in the 1950s. The three major German dye companies-Bayer, BASF, and Hoechst-again worked together in Hindustan Organic Chemicals Ltd., founded in 1960 in cooperation with the government of India, which owned 70 percent of the business. However, the project was short lived; the Germans stopped working on it in 1962. Bayer continued selling dyes and chemical products to India, but research has yet to establish how much continuity from the prewar business existed.

In conclusion, the German dye business confirms the claim that British India's openness to trade created opportunities for outsiders. In line with the most current research on Swiss and 
Japanese business interests in Asia, German firms were exploring India as a market and dominated the important dye business in the country. These German-Indian encounters are at odds with what has been called a Eurocentric perspective on India's economic development. This Eurocentric perspective in fact refers primarily to British and to a lesser extent Dutch interests in the region and is often plotted as an alternative to regional, intra-Asian economic linkages. The evidence in this article, however, suggests that the German experience may be more fittingly described in comparison with Japan. As late industrializers and outsiders of the colonial system, both Japan and Germany offered an alternative to the British. Both German and Japanese firms were able to take advantage of their status as late industrializers benefiting from the precedent set by Great Britain. Both offered an alternative path to development - one that was attractive to Indians because it provided access to much-needed resources and simultaneously responded to increasing nationalism in the region. Further comparative research is required to identify similarities and differences between the strategies of the two countries and to understand timeand industry-specific developments.

CHRISTINA LUBINSKI is associate professor at the Centre for Business History at Copenhagen Business School and was Newcomen Fellow at Harvard Business School in 20102011. Her most recent publications include an article on Siemens and Bayer in India (Enterprise \& Society, 2014) and the coedited volume Family Multinationals: Entrepreneurship, Governance, and Pathways to Internationalization (Routledge, 2013.)

${ }^{1}$ Dwijendra Tripathi, ed., "Business, Networks, and the State in India." Special issue, Business History Review 88, no. 1 (2014). For an overview of the status quo of research, see also Dwijendra Tripathi, The Oxford History of Indian Business (New Delhi, Oxford, New York, 2004), quote: 6.

${ }^{2}$ James Walvin, Fruits of Empire: Exotic Produce and British Taste, 1660-1800 (New York, 1997). W. G. Clarence-Smith and Steven Topik, eds., The Global Coffee Economy in Africa, Asia and Latin America, $1500-1989$ (Cambridge, New York, 2003). John Darwin, The Empire Project: The Rise and Fall of the British World-System, 1830-1970 (Cambridge, New York, 2009).

${ }^{3}$ Antoinette M. Burton, Empire in Question: Reading, Writing, and Teaching British Imperialism (Durham, 2011), 279. See also Durba Ghosh and Dane Keith Kennedy, eds., Decentring Empire: Britain, India, and the Transcolonial World (Hyderabad, 2006). 
${ }^{4}$ Claude Markovits, The Global World of Indian Merchants, 1750-1947: Traders of Sind from Bukhara to Panama (Cambridge, 2000). Takeshi Hamashita, China, East Asia and the Global Economy: Regional and Historical Perspectives (Milton Park, New York, NY, 2008). Chhaya Goswami, The Call of the Sea: Kachchhi Traders in Muscat and Zanzibar, c. 1800-1880 (New Delhi, 2011). Christof Dejung, Die Fäden des globalen Marktes: Eine Sozial- und Kulturgeschichte des Welthandels am Beispiel der Handelsfirma Gebrüder Volkart 1851 1999 (Köln, 2013).

${ }^{5}$ Sven Beckert, Empire of Cotton: A Global History (New York, 2014).

${ }^{6}$ Sugihara Kaoru, "Japan as an Engine of the Asian International Economy, c. 1880-1936," Japan Forum 2, no. 1 (1990): 127-45. Shigeru Akita and Nicholas White, eds., The International Order of Asia in the 1930s and 1950s (Farmham, UK; Burlington, VT, 2010). Shigeru Akita and Naoto Kagotani, "The International Order of Asia in the 1930s," in Gentlemanly Capitalism, Imperialism, and Global History, ed. Shigeru Akita (Houndmills, New York, 2002), 143-67.

${ }^{7}$ Kris Manjapra, Age of Entanglement: German and Indian Intellectuals across Empire (Cambridge, MA, 2014). See also Jörg Esleben, Christina Kraenzle, and Sukanya Kulkarni, eds., Mapping Channels between Ganges and Rhein: German-Indian Cross-Cultural Relations (Middlesex, 2008).

${ }^{8}$ Tirthankar Roy, "Economic History and Modern India: Redefining the Link," The Journal of Economic Perspectives 16, no. 3 (2002): 109-30 here: 110. Tirthankar Roy, The Economic History of India, 1857-1947, 3rd ed. (New Delhi, 2011), 16.

${ }^{9}$ Dirk van Laak, Über alles in der Welt: Deutscher Imperialismus im 19. und 20. Jahrhundert (München, 2005), 109. Sebastian Conrad, Globalisation and the Nation in Imperial Germany (Cambridge, 2010).

${ }^{10}$ John Gallagher and Ronald Robinson, "The Imperialism of Free Trade," Economic History Review 6 (1953): 1-15.

${ }^{11}$ Christina Lubinski, "Liability of Foreignness in Historical Context: German Business in Preindependence India (1880-1940)," Enterprise \& Society 15, no. 4 (2014): 722-58.

${ }^{12}$ As excellently described by Dejung, Fäden des globalen Marktes.

${ }^{13}$ For World War I, see Maia Ramnath, Haj to Utopia: How the Ghadar Movement Charted Global Radicalism and Attempted to Overthrow the British Empire (University of California Press, 2011). Subhas Chandra Bose's cooperation with the German government during World War II has been described in great detail; see Sugata Bose, His Majesty's Opponent: Subhas Chandra Bose and India's Struggle Against Empire (Cambridge, MA, 2011). Romain Hayes, Subhas Chandra Bose in Nazi Germany: Politics, Intelligence and Propaganda, 1941-43 (New York, 2011). Jan Kuhlmann and Christel Das, Netaji in Europe (New Delhi, 2012). and Milan Hauner, India in Axis Strategy: Germany, Japan, and Indian Nationalists in the Second World War (Stuttgart, 1981).

${ }^{14}$ One notable exception is Raman Mahadevan, "Wrangling over the Colonial Indian Market: The Untold Story of German Commercial Presence between the Wars" (paper presented at the "Informal and Everyday Markets: Modern Histories of Indian Business and Entrepreneurship since the Nineteenth Century” workshop, University of Goettingen, 18-20 June 2014). 
${ }^{15}$ David Arnold, Everyday Technology: Machines and the Making of India's Modernity (Chicago, 2013). Mona Domosh, American Commodities in an Age of Empire (New York, NY, 2006). Christina Lubinski, "Local Responsiveness in Distant Markets: Western Gramophone Companies in India before World War I," Management and Organizational History 10, no. 2 (2015): 170-88.

16 Aparajith Ramnath, Engineers in India: Industrialisation, Indianisation and the State, 1900-47 (Unpublished PhD thesis, Imperial College London 2012).

${ }^{17}$ Jeffrey Fear, "Cartels," in The Oxford Handbook of Business History, ed. Geoffrey Jones and Jonathan Zeitlin (Oxford, 2008), 268-92, here: 275.

${ }^{18}$ Ian Tyrrell, "Reflections on the Transnational Turn in United States History: Theory and Practice," Journal of Global History 4, no. 3 (2009): 453-74.

${ }^{19}$ Werner Abelshauser et al., German Industry and Global Enterprise: BASF - The History of A Company (Cambridge, UK, 2004), 97, 190. Gottfried Plumpe, Die I.G. Farbenindustrie AG: Wirtschaft, Technik und Politik 1904-1945, Schriften zur Wirtschafts- und Sozialgeschichte, (Berlin, 1990), 117-8, 571. Stephan H. Lindner, Inside IG Farben: Hoechst During the Third Reich (Cambridge, New York, 2008). Wilhelm Bartmann, Zwischen Tradition und Fortschritt. Aus der Geschichte der Pharmabereiche von Bayer, Hoechst und Schering von 1935-1975 (Stuttgart, 2003).

${ }^{20}$ The universities of Goettingen and Berlin are currently engaged in a joint research project, funded by the German Research Foundation, that will make German archival materials on India available; see http://gepris.dfg.de/gepris/projekt/259639080.

${ }^{21}$ Matthias Kipping, Marcelo Bucheli, and R. Daniel Wadhwani, "Analyzing and Interpreting Historical Sources: A Basic Methodology," in Organizations in Time: History, Theory, Methods, ed. Marcelo Bucheli and R. Daniel Wadhwani (Oxford, 2014), 305-29. Stephanie Decker, "The Silence of the Archives: Business History, PostColonialism and Archival Ethnography," Management and Organizational History 8, no. 2 (2013): 155-73.

${ }^{22}$ Mira Roy, "Dyes in Ancient and Medieval India," Indian Journal of History of Sciences 13, no. 2 (1978): 83-113 here: 83.

${ }^{23}$ Ernst Bäumler, Farben, Formeln, Forscher: Hoechst und die Geschichte der industriellen Chemie in Deutschland (München, 1989). Abelshauser et al., German Industry and Global Enterprise. For a detailed description of the changing market structure, see Alexander Engel, Farben der Globalisierung: Die Entstehung moderner Märkte für Farbstoffe 1500 - 1900 (Frankfurt/Main, New York, 2009). and Anthony S. Travis, The Rainbow Makers: The Origins of the Synthetic Dyestuffs Industry in Western Europe (Bethlehem, London, 1993).

${ }^{24}$ Alexander Engel, "Colouring Markets: The Industrial Transformation of the Dyestuff Business Revisited," Business History 54, no. 1 (2012): 10-29.

${ }^{25}$ Prakash Kumar, Indigo Plantations and Science in Colonial India (Cambridge, New York, 2012).

${ }^{26}$ U.S. Tariff Commission, Census of Dyes and Other Synthetic Organic Chemicals: 1922 (Washington, D.C., 1923), 124. 
${ }^{27}$ Elias G. Carayannis and Raymond Stokes, "A Historical Analysis of Management of Technology at Badische Anilin und Soda Fabrik (BASF), AG: A Case Study," Journal of Engineering and Technology Management 14, no. 2 (1997): 175-93.

${ }^{28}$ U.S. Tariff Commission, Census of Dyes 1922, 125, table 21.

${ }^{29}$ Great Britain, India Office, Tables Relating to the Trade of British India with the British Empire and Foreign Countries, 1909-10 to 1913-14 (London, 1915), 150-68.

${ }^{30}$ U.S. Tariff Commission, Census of Dyes and Other Synthetic Organic Chemicals: 1923 (Washington, D.C., 1924), 153.

31 Geoffrey Jones, Merchants to Multinationals: British Trading Companies in the Nineteenth and Twentieth Centuries (Oxford, 2000), 26.

${ }^{32}$ Bayer, Geschichte und Entwicklung der Farbenfabriken vorm. Friedr. Bayer \& Co. Elberfeld in den ersten 50 Jahren (Munchen, 1918), 400-2.

${ }^{33}$ India/Memorandum by C. Rumpff, 10 Dec. 1888, 82.1, Bayer Archives, Leverkusen (hereafter BA).

${ }^{34}$ Dhruv Raina and S. Irfan Habib, "Technical Institutes in Colonial India Kala Bhavan, Baroda (18901990)," Economic and Political Weekly 26, no. 46 (1991): 2619-21 here: 2619-20, appendix 1. Rajesh Kochhar, "Tribhuvandas Kalyandas Gajjar (1863-1920): The Pioneering Industrial Chemist of Western India," Current Science 104, no. 8 (2013): 1093-97.

${ }^{35}$ T. K. Gajjar, "Welcome Address," The Industrial Conference Held at Surat, December 1907: Full Text of Papers Read at and Submitted to it, ed. by The Industrial Conference (Madras, 1907), 1-21, here: 9-10.

${ }^{36}$ Makrand Mehta, "Science versus Technology: The Early Years of the Kala Bhavan, Baroda, 1890-1896," Indian Journal of History of Science 27, no. 2 (1992): 145-70 here: 157. Bayer, Geschichte und Entwicklung, 400.

${ }^{37}$ Bayer Group, Bayer Group in India (undated), http://www.ibef.org/download/bayer.pdf.

${ }^{38}$ Based on 5 E.a. 16 "Report to the Bayer Advisory Board" Apr. 1902, 5; 202/16 "Peace Negotiations World War I," Mar. 1918; both at BA.

${ }^{39}$ Abelshauser et al., German Industry and Global Enterprise, 96-7.

${ }^{40}$ This organization inspired U.S. and British competition during and after World War I; see Great Britain Trade Commissioner for India, Trade of India: Report on the Conditions and Prospects of British Trade in India, at the close of the War , by His Majesty's Senior Trade Commissioner in India and Ceylon (London, 1919), 54.

41 "R. W. Carlyle's Report on the Agitation against the Partition (1905)," Pol. (Pol.) F. No.86(J)/1905, West Bengal State Archives, Kolkata (hereafter WBSA).

${ }^{42}$ Sumit Sarkar, The Swadeshi Movement in Bengal, 1903-1908 (New Delhi, 1973), 8-12.

${ }^{43}$ Sri Aurobindo, "The Aims of the Nationalist Party [Speech Delivered in Nagpur 30 Jan. 1908]," in The Complete Works of Sri Aurobindo: Vol. 6 and 7: Bande Mataram Political Writings and Speeches 1890-1908, ed. Sri Aurobindo Ashram Trust (Pondicherry, 2002), 846-54, here: 852.

44 "R. W. Carlyle's Report on the Agitation against the Partition (1905)," Pol. (Pol.) F. No.86(J)/1905, WBSA. 
${ }^{45}$ Howard Payn, The Merchandise Marks Act 1887, with special reference to the importation sections and the customs regulations and orders made thereunder (London, 1888).

${ }^{46}$ Government of India, Dispatch No. 91, dated 14 Mar. 1901, reprinted in Report of the Bombay Chamber of Commerce for the Year 1901 (Bombay, 1902), 220.

${ }^{47}$ Government of India Legislative Department, Legislation and Orders Relating to the War, 3 ed. (Delhi, 1915).

48 "Enemy Trading in India," Bill, HL Deb, 27 Jan. 1916, vol. 20, cc.1092-99, Hansard 1803-2005, http://hansard.millbanksystems.com/lords/1916/jan/27/enemy-trading-in-india.

49 "Detention and Internment of German and Austrian Subjects," Correspondence between American Consulate and Secretary of States, 19 Nov. 1915, Records of the Department of State Relating to World War I and Its Termination, 1914-1929, M367, 59, National Archives and Records Administration, Washington, D.C. (hereafter NARA).

${ }^{50}$ Christof Dejung and Andreas Zangger, "British Wartime Protectionism and Swiss Trading Companies in Asia during the First World War," Past \& Present 207, no. 1 (2010): 181-213 here: 197-9.

${ }^{51}$ Friedrich von Bernhardi, Germany and the Next War (New York, 1914). Thomas G. Fraser, "Germany and Indian Revolution, 1914-18," Journal of Contemporary History 12, no. 2 (1977): 255-72 here: 256-7.

${ }^{52}$ Ramnath, Haj to Utopia.

${ }^{53}$ Great Britain Trade Commissioner for India, Trade of India, 53.

${ }^{54}$ Ibid., 12.

55 “Auction Sale of Dyes: High Prices Realised in Madras," Times of India, 12 July 1916, 5.

56 "Shortage of Dyes," Times of India, 23 Mar. 1916, 8.

${ }^{57}$ Great Britain Trade Commissioner for India, Trade of India, 54.

${ }^{58}$ For details on the I.G., see Plumpe, I.G. Farbenindustrie AG, 96-100. Abelshauser et al., German Industry and Global Enterprise, 171-3.

${ }^{59}$ Jeffrey Allan Johnson and Roy M. Macleod, "The War the Victors Lost: The Dilemmas of Chemical Disarmament, 1919-1926," in Frontline and Factory: Comparative Perspectives on the Chemical Industry at War, 1914-1924, ed. Roy M. Macleod and Jeffrey Allan Johnson (Dordrecht, 2006), 221-45.

${ }^{60}$ Ibid., 222-3. Margit Szöllösi-Janze, "Losing the War but Gaining Ground: The German Chemical Industry during World War I," in The German Chemical Industry in the Twentieth Century, ed. John E. Lesch (Dordrecht, 2000), 91-121. See also Kathryn Stehen, The American Synthetic Organic Chemicals Industry: War and Politics, 1910-1930 (Chapel Hill, N.C., 2014).

${ }^{61}$ Erez Manela, The Wilsonian Moment: Self-Determination and the International Origins of Anticolonial Nationalism (Oxford, New York, 2007), 95-7.

${ }^{62}$ Lionel Curtis and Great Britain Parliament, Papers Relating to the Application of the Principle of Dyarchy to the Government of India (Oxford, 1920).

${ }^{63}$ India Fiscal Commission, Report of the Indian Fiscal Commission 1921-22 (Simla, 1922), 137.

${ }^{64}$ Pramathanath Banerjea, Fiscal Policy in India (London, 1922), 176. 
${ }^{65}$ Lisa Trivedi, Clothing Gandhi's Nation: Homespun and Modern India (Bloomington, 2007), 5-9, quote:

36. See also the analysis of the German consul in Calcutta: Dr. Pausch to German Foreign Office, 20 Dec. 1938, British-India 330-442, BA.

66 "Report on the visit of Das Gupta, 1921," 9 K 1 AG, BA. About Das Gupta see Niroda Kumāra Baruwā, Chatto: The Life and Times of an Indian Anti-Imperialist in Europe (New Delhi, New York, 2004), 43-4.

${ }^{67}$ On German cloaking strategies, see also Gerard Aalders and Cees Wiebes, The Art of Cloaking Ownership: The Secret Collaboration and Protection of the German War Industry by the Neutrals: The Case of Sweden (Amsterdam, 1996). Geoffrey Jones and Christina Lubinski, "Managing Political Risk in Global Business: Beiersdorf 1914-1990," Enterprise \& Society 13, no. 1 (2012): 85-119. Christopher Kobrak and Per. H. Hansen, eds., European Business, Dictatorship, and Political Risk, 1920-1945 (New York, 2004).

${ }^{68}$ Bayer to I.G. Farben firms, 27 Oct. 1921, Sales Dyes 420, BA.

${ }^{69}$ Bayer to Gorio, 16 Mar. 1921, Sales Dyes 420, BA.

70 "Treaty of Commerce and Navigation between the United Kingdom and Germany," 2 Dec. 1924, ratified 8 Sept. 1925; printed in: Great Britain. Foreign Office, Handbook of Commercial Treaties, etc., With Foreign Powers, 4 ed. (London, 1931), 299.

${ }^{71}$ Alfred D. Chandler, Scale and Scope: The Dynamics of Industrial Capitalism (Cambridge, MA, 1990), 475. Plumpe, I.G. Farbenindustrie AG.

${ }^{72}$ Sole Importer Contract, I.G. and Havero, 19 A 590-2, BA; "Secret Agreement with Havero, British India," 9 K 12 , BA.

${ }^{73}$ For details on I.G. Farben's international business and cloaking, see Mira Wilkins, The History of Foreign Investment in the United States, 1914-1945 (Cambridge, MA, 2004), 462-69. More sophisticated cloaking arrangements were common in the interwar period. For context see Aalders and Wiebes, Art of Cloaking; Jones and Lubinski, "Managing Political Risk."

74 “Our Sales Organization until the War," Chemicals 330/1088, BA; Tax issues, British India 9 K 1 2, and letter from Havero to IG, 24 June 1929, BA. See also "Income Tax Claim,” Times of India, 22 Mar. 1928, 15.

${ }^{75}$ U.S. Tariff Commission, Census of Dyes 1923, 123.

${ }^{76}$ U.S. Tariff Commission, Census of Dyes and Other Synthetic Organic Chemicals: 1926 (Washington, D.C., 1927), 148.

77 Consul W. Keblinger, Bombay, "Chemical Division Market for Aniline Dyes in India," 5, U.S. Department of Commerce, Special Circular No. 221, R8128/5484, Federal Archives, Berlin (hereafter BArch).

${ }^{78}$ For this detailed market analysis, see ibid., 4-10; "Havero's Dye Business in British India," 1 Feb. 1938, R 8128/9967, BArch.

79 "Critical Notes on the Selling of I.G. Products in East-Asian Countries," Apr. 1929, "Carl Duisberg's Travel Reports,” vol. 6, BA; R 8128/9967 “Havero's Dye Business in British India,” BArch.

${ }^{80} \mathrm{R}$ 8128/9967, “Havero's Dye Business in British India,” XI, BArch.

${ }^{81}$ Kapp to Foreign Office, 30 June 1927, R3101-21030, BArch; “Confidential Report on the Indian Boycott," undated [1930], R3101-02664, BArch. 
82 I.G./British India, 330/1267 "Collection of documents on trademarks," BA; Plumpe, I.G. Farbenindustrie AG, 118; W. J. Reader, Imperial Chemical Industries: A History. 2 vols. (London, 1970), vol. 1, 439.

83 A. D. D. Gordon, Businessmen and Politics: Rising Nationalism and a Modernising Economy in Bombay, 1918-1933 (New Delhi, 1978), 210-18. Claude Markovits, Indian Business and Nationalist Politics, 1931 1939: The Indigenous Capitalist Class and the Rise of the Congress Party (Cambridge, 1985), 72-6.

${ }^{84}$ Grobba, Foreign Office, to Winter Reisner \& Co., 16 May 1930, R3101-02664, BArch.

85 "Confidential Report on the Indian Boycott," BArch.

${ }^{86}$ Kim Coleman, IG Farben and ICI, 1925-53: Strategies for Growth and Survival (Houndmills, Basingstoke, 2006), 54. Plumpe, I.G. Farbenindustrie AG, 197-9, 455.

87 “World Dye Production, Percentage of World Trade by the Cartel," 1933, 4.B.14.3.6, BA.

${ }^{88}$ K. A. Manikumar, A Colonial Economy in the Great Depression, Madras (1929-1937) (Chennai, 2003), 100. "New Taxation Not Justified: A Bad Precedent, Ahmedabad Millowners' Protest," Times of India, 12 Oct. $1931,11$.

89 “An Act to Consolidate the Law Relating to Customs Duties," Act 32, A Collection of the Acts of the Indian Legislature for the Year 1934 (New Delhi 1934).

${ }^{90}$ J. Adam Tooze, The Wages of Destruction: The Making and Breaking of the Nazi Economy (New York, 2007), 71-86.

91 “Havero's Dye Business in British India,” BArch.

${ }^{92}$ Ibid.

${ }^{93}$ German consulate Bombay [Richter] to Foreign Office, 11 Nov. 1932, R 90656, Politisches Archiv in Berlin (German Foreign Office Archives; hereafter PA). See also Maria Framke, Delhi - Rom - Berlin: Die indische Wahrnehmung von Faschismus und Nationalsozialismus 1922 - 1939 (Darmstadt, 2013).

${ }^{94}$ For a detailed analysis of the election results and the relationship of the INC to the Indian business class, see Claude Markovits, "Indian Business and the Congress Provincial Governments 1937-39," Modern Asian Studies 15, no. 3 (1981): 487-526.

${ }^{95}$ Travel reports, Reithinger, 191/1/3, BA.

${ }^{96}$ Ibid. On Reithinger, see also Peter Hayes, Industry and Ideology: IG Farben in the Nazi Era (Cambridge, New York, 1987), 31. Lubinski, "Liability of Foreignness," 738-9. On INC governments' purchasing policy, see Markovits, "Indian Business," 503.

${ }^{97}$ Harijan, 26 Mar. 1938, reprinted in Jag Parvesh Chander, ed. Teachings of Mahatma Gandhi (Lahore, 1945), 539.

98 "Reorganization of our [Havero's] Indian Dye Business" 1938, 7, 9 and 31, 191/1/3, BA.

99 “Confidential Note,” Dec. 1938, Legal Department, 330/1114, BA.

100 "Reorganization of our [Havero's] Indian Dye Business" 1938, 33, 330/1124, BA.

${ }^{101}$ Series of letters and "Confidential Note", Dec. 1938, Chemdyes Ltd., Correspondence I, 1938-42, Legal Department, 330/1114, BA. 
102 Joan G. Roland, The Jewish Communities of India: Identity in a Colonial Era (New Brunswick, N.J., 1998).

${ }^{103}$ See also Manjapra, Age of Entanglement, 80-5. Framke, Delhi - Rom - Berlin. Yulia Egorova, Jews and India: Perceptions and Image (Abingdon, New York, 2006), 43.

104 “Mr. Nambiar's Aweful Ordeal: How He Was Treated by Nazi Storm Troopers," Advance, 11 May 1933. Christoph Kreutzmüller, "Augen im Sturm? Ausländische Zeitungsberichte über die Judenverfolgung in Berlin 1918-1938," Zeitschrift für Geschichtswissenschaft 62, no. 1 (2014): 25-48.

105 "Reports on anti-German boycotts," 1934-1935, R 98706, PA.

${ }^{106}$ Consulate in Bombay to Foreign Office, 6 and 10 Feb. 1936, R 77418, PA.

107 Jewish Tribune, Mar. 1936, 3, quoted in Egorova, Jews and India, 43.

${ }^{108}$ Havero to I.G., 15 Aug. 1938, Reorganization British India, 330/1111, BA.

${ }^{109}$ Urchs to Kuepper, 9 Dec. 1938, Chemdyes Ltd., Bombay, Correspondence I, 1938-42, 330/1114, BA.

110 “Germans in enemy countries,” 1939-1945, R 127578, PA; “Civil internees,” 1939-1945, R 4181941822, PA.

${ }^{111}$ D I B's reports on activities of Germans, Italians, and Japanese in India, File 1080(A)/36: July 1939Feb. 1940, Survey No. 19, IOR/L/PJ/12/506, British Library, India Office Records.

112 „Propaganda in India,“ 1941, R 55/20822, BArch.

${ }^{113}$ For details on German-Indian relations during World War II, see Hauner, India in Axis Strategy. Kuhlmann and Das, Netaji in Europe. 